\title{
Shading, Growth, and Dry-matter Partitioning of Cocoyam [Xanthosoma sagittifolium (L.) Schott]
}

\author{
Hector R. Valenzuela, Stephen K. O'Hair, and Bruce Schaffer \\ Tropical Research and Education Center, University of Florida, Institute of Food and Agricultural \\ Sciences, 18905 S. W. 280 Street, Homestead, FL 33031-3314 \\ Additional index words. aroids, tannia, light interception, photosynthesis
}

\begin{abstract}
Cocoyam was grown in $100 \%, 50 \%$, or $30 \%$ daylight to determine the effect of light intensity on growth characteristics at various stages of plant development. Beginning $\approx 2$ months after planting, growth was monitored at three or four monthly intervals. Plants grown in shade had more petiole and leaf lamina growth and extension, as well as increased top : corm plus cormel ratio (dry-weight basis), than plants grown in $100 \%$ daylight. Shade-grown plants had a higher leaf area index and specific leaf area than sun-grown plants. Sun-grown plants had a higher net assimilation rate and specific leaf density than shade-grown plants. Linear equations were developed to predict lamina area through measurements of leaf lamina width and length, petiole length, and lamina dry weight.
\end{abstract}

Cocoyam is an herbaceous, perennial, tropical herb grown for its edible starch-filled corms and cormels. The rhizome-like cormels, the part most often consumed, arise from the base of the corm below the soil surface (0'Hair and Asokan, 1986). Since cocoyam has been identified as a shade-tolerant crop (Caesar, 1980; Schaffer and O'Hair, 1987), the potential exists to use it as an understory crop in polyculture or agroforestry production systems (Juo, 1989). Multistory polyculture systems can lead to maximization of light interception and resource utilization. Information on cocoyam growth, ontogeny, phenology, and dry-matter partitioning patterns under differing photosynthetic photon flux (PPF) levels may assist in designing such systems. Field studies with cocoyam or related edible aroids have demonstrated a steady increase in foliage production during the first 5 months of growth (Enyi, 1968; Ezumah and Plucknett, 1981; Okoli, 1980; Spence, 1970). Maximum standing crop biomass was achieved between 6 and 9 months after planting, followed by a shift in partitioning of photosynthates into corms and cormels (Enyi, 1968; Okoli, 1980; Sobulo, 1972; Spence, 1970). Depending on environmental conditions, corm and cormel biomass continued to increase until a plateau was reached by 7 to 10 months after planting (Enyi, 1968; Okoli, 1980; Sobulo, 1972; Spence, 1970). Positive correlations between lamina area and corm dry weight and also between plant height and corm dry weight have been suggested by some studies (Enyi, 1968; Spence, 1970). Caesar (1980) observed an increase in biomass when cocoyam was grown in $20 \%$ daylight $\left(\mathrm{PPF} \approx 300 \mu \mathrm{mol} \cdot \mathrm{m}^{-2} \cdot \mathrm{s}^{-1}\right)$, relative to plants grown in $100 \%$ daylight. He attributed this increase to increased interception of incident PPF, which resulted from an increased petiole length and lamina area per plant.

The purpose of this study was to conduct a growth analysis of cocoyam under three PPF levels and determine the effect of light intensity on growth characteristics at various stages of plant development.

\section{Materials and Methods}

In two separate trials, 'South Dade White' cocoyam was grown in $100 \%, 50 \%$, or $30 \%$ daylight. Experiment 1 began 1 June

Received for publication 27 Nov. 1989. Florida Agricultural Experiment Stations Journal Series no. R-00294. The cost of publishing this paper was defrayed in part by the payment of page charges. Under postal regulations, this paper therefore must be hereby marked advertisement solely to indicate this fact.

'Present address: Dept. of Horticulture, Univ. of Hawaii, Honolulu, HI 96822. and Expt. 2 began 28 Dec. 1988. Experiment 1 was concluded 16 Nov. 1988 and Expt. 2 on 4 July 1989. Mean integrated daily PPFs for the $100 \%$ sunlight treatments were 35.0 $\mathrm{mol} \cdot \mathrm{m}^{-2} \cdot \mathrm{day}^{-1}$ for Expt. 1 and $37.4 \mathrm{~mol} \cdot \mathrm{m}^{-2} \cdot \mathrm{day}^{-1}$ for Expt. 2 , as determined with a pyranometer (Model PSP; Eppley Laboratory, Newport, R.I.). Shade treatments were provided by 3 $\times 3 \times 1.5$-m cages covered with selected woven polyethylene fabrics providing $50 \%$ and $30 \%$ daylight.

One-half of the plant population used in Expt. 1 was grown in either $30 \%$ or $100 \%$ daylight and used for growth analysis (Expt. 1A). The remaining plants in Expt. 1 (Expt. 1B) were grown in 30\%, 50\%, and 100\% daylight and used for nondestructive growth determinations. Propagules, $\approx 300 \mathrm{~g}$ consisting of the top portion of main corms selected from a recently harvested commercial field, were potted in 1 peat : 1 sand $(\mathrm{v} / \mathrm{v})$ in 7.5-liter containers. Plants were irrigated daily or every other day to maintain the growing medium near container capacity and fertilized twice weekly with $475 \mathrm{ppm} \mathrm{N}, 104 \mathrm{ppm}$ $\mathrm{P}, 192 \mathrm{ppm} \mathrm{K}$, and micronutrients in the irrigation water. In Expt. 1A, beginning 75 days after planting (DAP), three monthly determinations were made of lamina length along the midrib section, maximum lamina width, lamina area [determined with a LI-COR LI-3000 leaf area meter (LI-COR, Lincoln, Neb.)], petiole length and number per plant (count), stem diameter at the soil surface, as well as fresh weights of laminas, petioles, and corms. The petioles consisted of the stem tissue that arose from the underground corm and extended to the leaf lamina. Each monthly harvest consisted of four plants per replication for each shade treatment. Determinations at each sampling date were made from all plant parts taken from each separate plant. Only photosynthetically active green tissue (lamina and petioles) was harvested from the foliage to facilitate growth analysis determinations. Tissue samples were oven-dried at $80 \mathrm{C}$ for $72 \mathrm{~h}$ before making dry weight determinations.

The following growth characteristics were calculated according to Hunt (1978): top : corm (main corm plus cormels) ratio (dry-weight basis), specific leaf density (SLD) (lamina dry weight divided by lamina area), specific leaf area (SLA) (the inverse of SLD) (Bjorkman, 1981), leaf area index (LAI), and net assimilation rate (net gain in weight over time per unit lamina area). In previous studies, equations were developed for estimating lamina area from measurements of lamina length and

Abbreviations: DAP, days after planting, LAI, leaf area index; PPF, photosynthetic photon flux SLA, specific leaf area. 
Table 1. Effect of shade on petiole length, number of petioles per plant, lamina area per plant, and stem diameter in cocoyam (Xanthosoma sagittifolium).

\begin{tabular}{|c|c|c|c|c|c|c|c|c|c|c|c|c|}
\hline \multirow{3}{*}{$\begin{array}{l}\text { Portion of } \\
\text { daylight }(\%)\end{array}$} & \multicolumn{3}{|c|}{$\begin{array}{l}\text { Petiole } \\
\text { length } \\
(\mathrm{cm})\end{array}$} & \multicolumn{6}{|c|}{$\begin{array}{c}\text { Lamina area/ } \\
\text { plant } \\
\left(\mathrm{cm}^{2}\right)\end{array}$} & \multicolumn{3}{|c|}{$\begin{array}{l}\text { Stem diam } \\
(\mathrm{mm})\end{array}$} \\
\hline & \multicolumn{12}{|c|}{ Expt. $^{z}$} \\
\hline & $1 \mathrm{~A}$ & $1 \mathrm{~B}$ & 2 & $1 \mathrm{~A}$ & $1 \mathrm{~B}$ & 2 & $1 \mathrm{~A}$ & $1 \mathrm{~B}$ & 2 & $1 \mathrm{~A}$ & 1B & 2 \\
\hline 100 & 43.2 & 27.9 & 36.9 & 2.8 & 2.3 & 2.0 & 1121 & 911 & 498 & 41 & 27 & 34 \\
\hline 50 & ...y & 44.6 & 43.8 & -.. & 2.8 & 3.1 & --- & 1511 & 1105 & -- & 33 & 43 \\
\hline 30 & 76.8 & 74.0 & 50.9 & 3.4 & 3.9 & 3.1 & 2801 & 1773 & 1622 & 45 & 33 & 41 \\
\hline \multicolumn{13}{|l|}{ Significance } \\
\hline Daylight & $* *$ & $* *$ & $* *$ & $* *$ & $* *$ & $* *$ & $* *$ & $* *$ & $* *$ & $* *$ & $* *$ & $* *$ \\
\hline Daylight linear ${ }^{w}$ & $--\cdot$ & $* *$ & $* *$ & --- & $* *$ & --- & --- & $* *$ & $* *$ & --- & --- & -- \\
\hline Daylight quadratic ${ }^{w}$ & -- & $* *$ & $* *$ & -- & $* *$ & $* *$ & --- & $* *$ & $* *$ & --- & -- & -- \\
\hline
\end{tabular}

${ }^{\mathrm{z}} 1 \mathrm{~A}=$ mean of 48 measurements taken at 74,105 , and $135 \mathrm{DAP} ; 1 \mathrm{~B}=$ mean of 32 measurements taken at $30,60,90$, and 120 DAP; $2=$ mean of 16 measurements taken at 30, 60, 90, and 120 DAP. 'Determinations were made only for plants growing in $305 \%$ and $100 \%$ daylight.

'Significance determined by analysis of variance $\mathrm{F}$ test $(P<0.05)$.

'Significance detemined by orthogonal contrast analysis $(\mathrm{P}<0.05)$.

Table 2. Effect of shade on leaf, petiole, and corm dry weights and top: corm ratio (dry weight) in cocoyam in Expts. 1A and 2.

\begin{tabular}{|c|c|c|c|c|c|c|c|c|}
\hline \multirow{4}{*}{$\begin{array}{l}\text { Portion of } \\
\text { daylight }(\%)\end{array}$} & \multicolumn{8}{|c|}{ Dry wt $(\mathrm{g})$} \\
\hline & \multicolumn{2}{|c|}{ Leaf } & \multicolumn{2}{|c|}{ Petiole } & \multicolumn{2}{|c|}{ Corm $^{2}$} & \multicolumn{2}{|c|}{$\begin{array}{c}\text { Top : corm } \\
\text { ratio }^{z}\end{array}$} \\
\hline & \multicolumn{8}{|c|}{ Expt. $y$} \\
\hline & $1 \mathrm{~A}$ & 2 & $1 \mathrm{~A}$ & 2 & $1 \mathrm{~A}$ & 2 & $1 \mathrm{~A}$ & 2 \\
\hline 100 & 5.1 & 4.0 & 7.4 & 6.5 & 51.4 & 96 & 0.25 & 0.11 \\
\hline 50 & $\ldots x$ & 6.3 & --- & 15.8 & --- & 122 & -- & 0.18 \\
\hline 30 & 10.8 & 6.2 & 16.2 & 17.4 & 53.5 & 120 & 0.50 & 0.20 \\
\hline \multicolumn{9}{|l|}{ Significance } \\
\hline Daylightw & $* *$ & $* *$ & $* *$ & $* *$ & NS & $* *$ & $* *$ & ** \\
\hline Daylight linear & $\ldots$ & $* *$ & -- & $* *$ & -- & $* *$ & $\ldots$ & ** \\
\hline Daylight quadratic & -- & NS & --- & NS & $-\ldots$ & NS & --- & NS \\
\hline
\end{tabular}

${ }^{\mathrm{z}}$ Main corm plus cormels.

${ }^{\mathrm{y}} 1 \mathrm{~A}=$ mean of 48 measurements taken at 75,105 , and 135 DAP; $2=$ mean of eight measurements taken at 210 DAP.

'Determinations were made only for plants growing in 30\% and 100\% daylight.

'Significance determined by analysis of variance $\mathrm{F}$ test $(\mathrm{P}<0.05)$.

'Significance determined by orthogonal contrast analysis $(\mathrm{P}<0.05)$.

width (Chapman, 1964; Ezumah and Plucknett, 1981; Shih and Snyder, 1984; Venkateswarlu and Birader, 1980). In the present study, we devised a similar equation for the cultivar investigated to allow future nondestructive lamina area determinations.

For Expt. 2, cultivar, propagule size, container size, soil mixture, fertilization, and irrigation were similar to that described for Expt. 1. In Expts. 1B and 2, monthly nondestructive determinations of petiole length and count, lamina length and width, and stem diameter at the soil surface were made over 4 months. Lamina area, in these experiments, was calculated on each sampling date based on the equation developed in Expt. 1A. In Expt. 2, plants were harvested at the end of the experimental period, and lamina, petiole, and corm fresh and dry weights were determined.

Each experiment was a randomized complete block design with four blocks per shading level. Each block consisted of a shade cage with each cage containing 12 or eight pots with one plant per pot. Pots were distanced $35 \mathrm{~cm}$ from each other to prevent competition for light among plants. Pots from Expt. 1 were distributed randomly within each cage, but statistical analysis was performed separately between Expts. 1 A and B. In Expts.
1B and 2, data were analyzed by orthogonal contrasts (Steel and Torrie, 1982). Data were transformed by taking the square root of $(x+0.5)$, where $x$ was the measured growth characteristic. Results presented are nontransformed data.

\section{Results}

The linear equation, lamina area $=69.27+0.87$ (lamina length $\times$ lamina width $)(\mathrm{r}=0.96 ; \mathrm{N}=233 ; P<0.01)$, facilitated subsequent nondestructive determinations of lamina area in Expts. 1B and 2. A linear relationship $(P<0.01)$ was also found between lamina area and petiole length $\{\log (\operatorname{lamina}$ area) $=1.03+1.01[\log ($ petiole length $)] ; \mathrm{r}=0.73 ; \mathrm{N}=$ $233\}$ and between lamina area and lamina dry weight (LDW) [lamina area $=190.42(\mathrm{LDW})+911.11 ; \mathrm{r}=0.46 ; \mathrm{N}=96$ ]. Linear relationships $(P<0.01, r<0.50)$ were also found between lamina area per plant, foliage fresh weight, and petiole length and corm fresh weight (data not shown).

Cocoyam grown in $30 \%$ daylight had a larger lamina area (Table 1) and more foliage dry matter (Table 2) than sun-grown (100\% daylight) plants. Increased lengths and numbers of pe- 
tioles and larger stem diameters for shaded plants (Table 1) resulted in increased top : corm ratios in Expts. 1A and 2 (Table 2). In Expt. 1A, top : corm ratios were higher for shade plants than for sun plants beginning 75 DAP (data not shown). Top : corm ratios by 135 DAP were 0.45 and 0.19 for shade and sun plants, respectively. Linear relationships were found between shade level and petiole length 90 DAP and between shade level and lamina area per plant 90 DAP (Fig. 1). There was a quadratic relationship between shade level and petiole count 90 DAP (Fig. 1). Shaded plants had more dry matter per plant than sun-grown plants beginning 105 DAP (Fig. 2).

Shade plants had a higher LAI and SLA (Fig. 3) than sungrown plants. Specific leaf density in Expts. 1A and 2 was higher $(\mathrm{P}<0.01)$ for sun than for shade plants, averaging 4.5 and $3.6 \mathrm{mg} \cdot \mathrm{cm}^{-2}$, respectively. Net assimilation rate was also higher for sun plants: between 105 and 135 DAP in Expt. 1A, it was 62.3 and $37.4 \mathrm{mg} \cdot \mathrm{m}^{-2} \cdot \mathrm{day}^{-1}$ for plants grown in $100 \%$ and $30 \%$ daylight, respectively.

Corm fresh weight was similar among treatments 75 DAP in Expt. 1A (data not shown). However, corm fresh weight in-

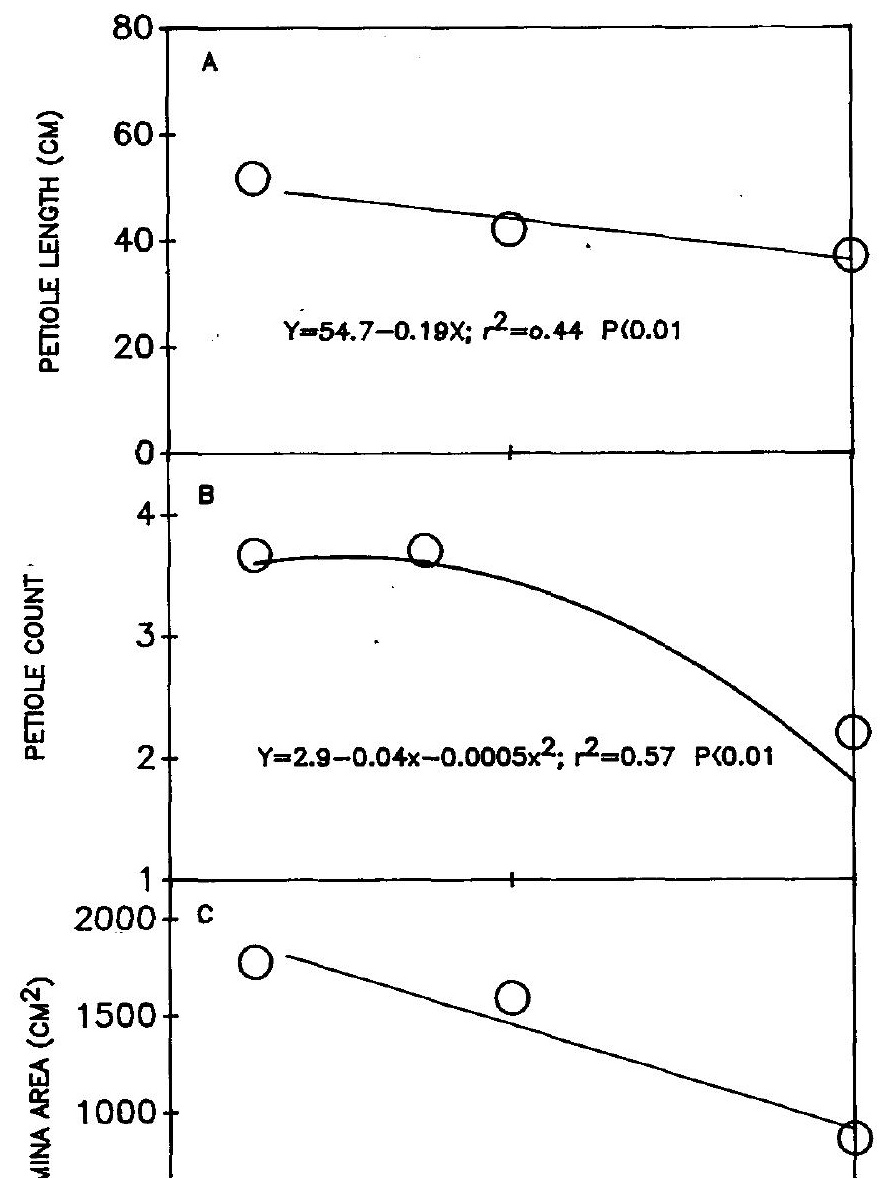

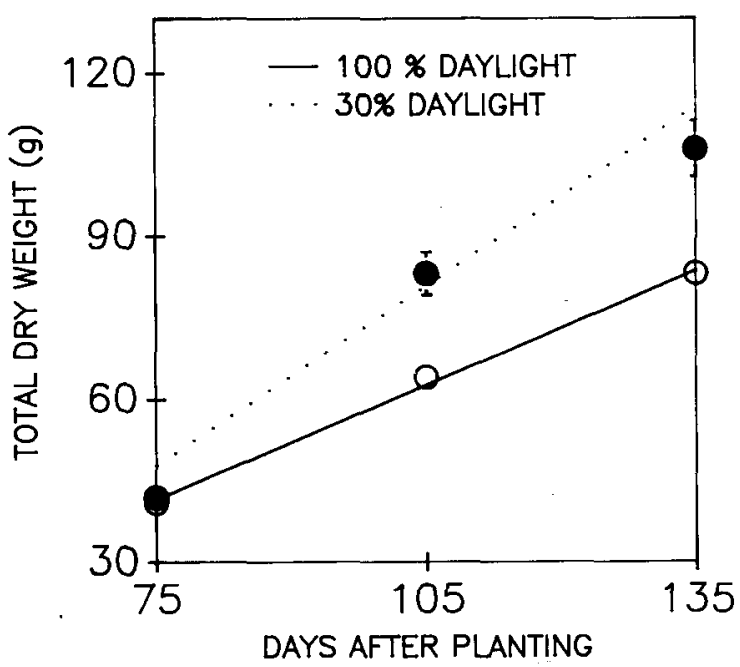

Fig. 2. Effect of percent daylight on total plant dry matter of cocoyam (Expt. 1A). Each point represents the mean of 16 determinations; Vertical bars represent \pm SE, $n=16$. In most cases, SE bars were smaller than the symbols. The lines were fit by regression $(\mathrm{N}=48)$ using the following equations: $100 \%$ daylight, $\mathrm{Y}=7.0-^{\mathrm{I}} \mathrm{X}-10.9$, $\mathrm{r}=0.77 ; 30 \%$ daylight, $\mathrm{Y}=1.1 \mathrm{X}-34.7, \mathrm{r}=0.72$.

creased to $490 \mathrm{~g}$ for shade plants compared to $465 \mathrm{~g}$ for sun plants 135 DAP. No significant difference in corm dry weight was detected between treatments over the length of the experiment (Table 2). However, corm dry weight for shade plants in Expt. 1A tended to be higher than for sun plants 135 DAP. Corm dry weight 135 DAP was 73 and $80 \mathrm{~g}$ for sun and shade plants, respectively. Corm dry weight at harvest was higher for shade plants (30\% and 50\% daylight) than for sun plants in Expt. 2 (Table 2).

\section{Discussion}

Cocoyam responded to increased shading (30\% and 50\% daylight) with an increased assimilation area, which resulted in greater biomass production and increased crop growth. The larger leaves and longer petioles obtained in the shade occupied more of the available area, leading to a greater light interception and to higher rates of carbon fixation on a per plant basis, as determined by monthly dry weight determinations and compared to plants grown in full sun. Therefore, the higher yields of underground components for shade-grown cocoyam also are attributable to more light interception by these plants than by those grown in full sun.

Shade plants also had a greater SLA (Fig. 3B) and a higher lamina : petiole weight ratio (data not shown). Similar shadeinduced changes in SLA have been reported for several other plant species (Barden, 1978; Bjorkman, 1981; Chabot et al., 1979; Singh et al, 1974; Weinbaum et al., 1989). Decreased lamina thickness with increased shade has been attributed to 


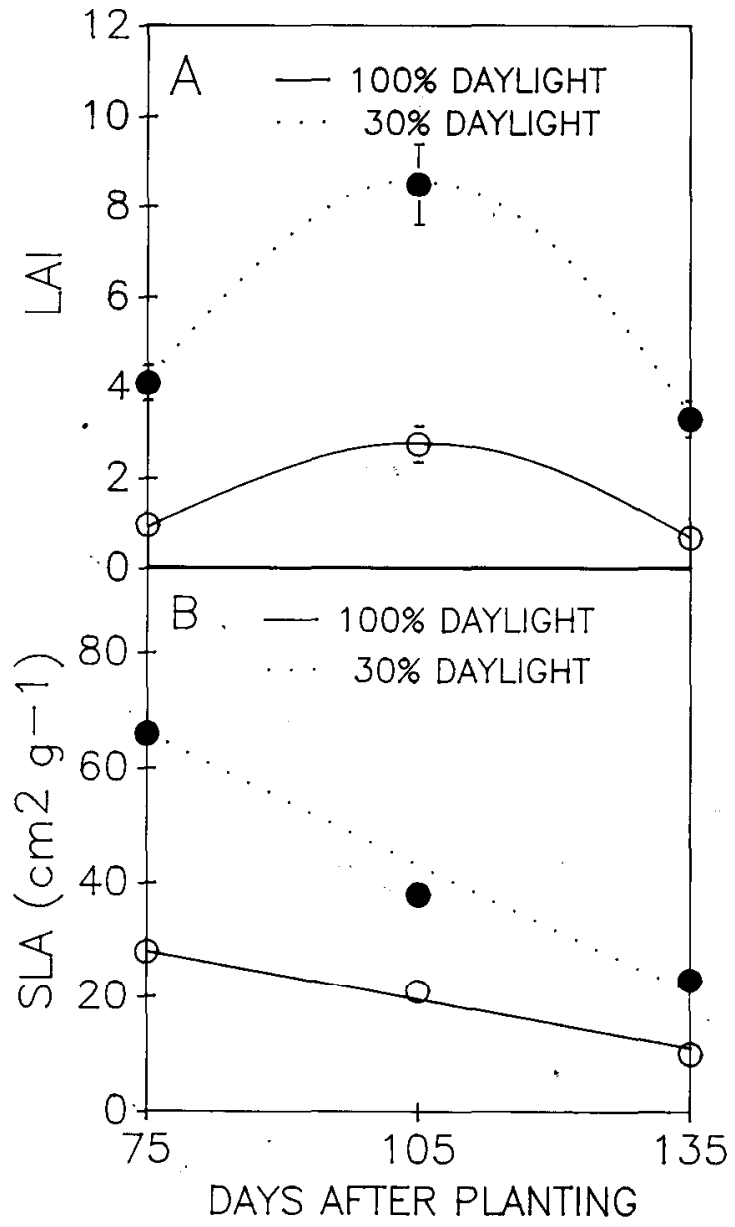

Fig. 3. Effect of percent daylight on LAI (A); and SLA (B) of cocoyam (Expt. 1A). Each point represents the mean of 16 determinations calculated at 75, 105, and 135 DAP. Vertical bars represent $\pm \mathrm{SE}, \mathrm{N}=4$. In most cases, SE bars were smaller than the symbols. Lines were fit by regression $(\mathrm{N},=48)$ using the following equations: LAI (sun), $\mathrm{Y}=4.5^{-1}(\mathrm{DAP})-2.2^{-3}(\mathrm{DAP})^{2}-20.9, \mathrm{r}-=0.82$; LAI (shade), $\mathrm{Y}=1.1$ (DAP). $-5.2^{-3}(\mathrm{DAP})^{2}-48.2, \mathrm{r}=0.81$; SLA (sun), $\mathrm{Y}=49.2-2.8^{-1}(\mathrm{DAP}), \mathrm{r}=0.92 ;$ SLA (shade), $\mathrm{Y}$ $=120.4-7.3^{-1}(\mathrm{DAP}), \mathrm{r}-=0.92$.

than shade plants, showing a greater photosynthetic productivity on a leaf-area basis than shade plants (Bjorkman, 1981). The larger SLA indicates that shaded plants had thinner laminas than those produced by sun-grown plants.

Shaded cocoyam partitioned more photosynthates to the foliage than to the storage organs compared to sun plants. However, by harvest time, shade plants had a greater whole-plant and storage organ dry weight (yield) than sun plants (Fig. 2 and Table 2), presumably due to the higher assimilation rate, on a whole-plant basis, for shade plants resulting from the larger lamina area.

Corm dry weight in Expt. 2 increased with decreasing light (30\% and 50\% vs. 100\% daylight). Caesar (1980) found similar corm dry weights for shaded and sun-grown cocoyam plants and a lower cormel dry weight with increased shade. However, in that study, the heaviest shading was only $20 \%$ of normal daylight, which may have been sufficient to seriously limit growth. For Amorphophallus, a related edible aroid, greater corm dry weights were obtained for plants grown in 40\% and 50\% daylight than in 30\% daylight (Miura and Osada, 1981).

Earlier measurements for Xanthosoma (Enyi, 1968; Spence,
1970), Amorphophallus (Miura and Osada, 1981), and Colocasia (Reddy et al., 1968) suggested a relationship between lamina area and corm dry weight. Our results corroborated these relationships, although our coefficients of determination were low $(r<0.50)$, perhaps attributable to the plant-to-plant variation and to the small sample size used in the analysis. The linear relationships observed between foliar growth (petiole length and lamina area) and incident PPF during growth (Fig. 1) could facilitate the design of planting patterns of polycultures. Planting patterns can be manipulated to help synchronize the percentage of light interception (or percent ground cover) with the potential productivity of the agroecosystem (Gardner and Auma, 1989).

The potential to increase cocoyam productivity in polyculture systems may be exploited through the plant's ability to use, with a high, degree of efficiency, the lower PPF levels found in typical understory situations. Management and crop improvement techniques could be devised to manipulate cocoyam canopy architecture, leaf production, planting distance, planting pattern, and timing of operations. Such changes should improve resource utilization (nutrients, light, and water) in tropical agroecosystems by improving light interception.

\section{Literature Cited}

Barden, J.A. 1978. Apple leaves, their morphology and photosynthetic potential. HortScience 13:644-646.

Bjorkman, O. 1981. Responses to different quantum flux densities, p. 57-107. In: O.L. Lange, P.S. Nobel, C.B. Osmond, and H. Ziegler (eds.). Physiological plant ecology. I. Encyclopedia of plant physiology. vol. 12A. Springer-Verlag, Berlin.

Caesar, K. 1980. Growth and development of Xanthsoma and Colocasia under different light and water supply conditions. Field Crops Res. 3:235-244.

Chabot, B. F., T.W. Jurik, and J.F. Chabot. 1979. Influence of instantaneous and integrated light-flux density on leaf anatomy and photosynthesis. Amer. J. Bet. 66:940-945.

Chapman, T. 1964. A note on the measurement of leaf area of the tannia (Xanthosoma sagittifolium). Trop. Agr. 41:351-352.

Enyi, B.A.C. 1968. Growth of cocoyam (Xanthosoma sagittifolium Schott). Indian J. Agr. Sci. 38:627-633.

Ezumah, H.C. and D.L. Plucknett. 1981. Cultural studies on tare, Colocasia esculenta (L) Schott. J. Root Crops 7:41-52.

Gardner, F.P. and E.O. Auma. 1989. Canopy structure, light interception, and yield and market quality of peanut genotypes as influenced by planting pattern and planting date. Field Crops Res. 20:13-29.

Goodchild, D. J., O. Bjorkman, and N.A. Pyliotis. 1972. Chloroplast ultrastructure, leaf anatomy, and content of chlorophyll and soluble protein in rainforest species. Carnegie Inst. Wash. Yearbook 71:102107.

Hunt, R. 1978. Plant growth analysis. Edward Arnold Publisher, London.

Juo, A.S.R. 1989. New farming systems development in the wetter tropics. Experimental Agr. 25:145-163.

Medina, E. 1971. Effect of nitrogen and light intensity during growth on the photosynthetic capacity and carboxydismutase activity of leaves of Atriplex patula spp. hastata. Carnegie Inst. Wash. Yearbook 70:551559.

Miura, K. and A. Osada. 1981. Effect of shading on photosynthesis, respiration, leaf area and corm weight in konjak plants (Amorphophallus konjak K. Koch). Jpn. J. Crop Sci. 50:553-559.

O'Hair, S.K. and M.P. Asokan. 1986. Edible aroids: Botany and horticulture. Hort. Rev. 8:43-99.

Okoli, 0.0. 1980. Dry matter accumulation and tuber sprouting in yams (Dioscorea spp.). Experimental Agr. 16:161-167.

Reddy, V. B., W.F. Meredith, and B.T. Brown. 1968. A note on the relationship between corm yield and certain leaf measurements in taro [Colocasia esculenta (L.) Schott]. Trop. Agr. 45:243-245. 
Schaffer, B. and S.K. O'Hair. 1987. Net $\mathrm{CO}_{2}$ assimilation of taro and cocoyam as affected by shading and leaf age. Photosyn. Res. 11:245251.

Shih, S.F. and G.H. Snyder. 1984. Leaf area index and dry biomass of tare. Agron. J. 76:750-753.

Singh, M., W.L. Ogren, and J.M. Widholm. 1974. Photosynthetic characteristics of several $\mathrm{C}_{3}$ and $\mathrm{C}_{4}$ plant species grown under different light intensities. Crop Sci. 14:563-566.

Sobulo, R.A. 1972. Studies on white yam (Dioscorea rotundata) I. Growth analysis. Experimental Agr. 8:99-106.
Spence, J.A. 1970. Growth and development of tannia (Xanthosoma sp.). Proc. Intl. Soc. Trop. Root Crops 2:47-52.

Steel, R.G.D. and J.H. Torrie. 1982. Principles and procedures of statistics. 2nd ed. McGraw-Hill, New York.

Venkateswarlu, T. and R.S. Biradar. 1980. Leaf area determination in tannia. J. Root Crops 6:45-49.

Weinbaum, S. A., S.M. Southwick, K.A. Schackel, T.T. Muraoka, W. Krueger, and J.T. Yeager. 1989. Photosynthetic photon flux influences macroelement weight and leaf dry weight per unit of leaf area in prune tree canopies. J. Amer. Soc. Hort. Sci. 114:720-723. 